\title{
Manajemen dan Peran BAZNAS Mengatasi Dampak Pademi Covid-19 Provinsi Bengkulu
}

\section{Management and Role of BAZNAS in Overcoming the Impact of Pademi Covid-19 Bengkulu Province}

\author{
Yenti Sumarni ${ }^{1}$, Esti Alfiah ${ }^{2}$
}

${ }^{1}$ Fakultas Ekonomi dan Bisnis Islam, IAIN Bengkulu, Bengkulu, Indonesia²Fakultas

Ekonomi dan Bisnis Islam, IAIN Bengkulu, Bengkulu, Indonesia

1yentisumarni@gmail.com, ${ }^{2}$ esti.alfiah2107@gmail.com

Manuscript received 09 April 2021, processed 14 April 2021, published 30 Juni 2021

\begin{abstract}
During this pandemic, amil zakat institutions are required to be able to contribute in handling the economic problems caused by the Covid-19 pandemic. Where zakat is specifically for the eight ashnaf groups, however, the conditions of the Covid-19 pandemic have an impact on many things. So that the purpose of this study is to find out how the management and role of amil zakat institutions in the use of zakat funds for victims of covid-19. This research uses descriptive analysis method. Whereas the management of BAZNAS in the past was related to 3 things, namely SDI, Money and Methods. Overall it has been good, so that $B A Z N A S^{\prime}$ 's role in dealing with impacts during the pademi has been resolved and $B A Z N A S^{\prime}$ 's goals are achieved.
\end{abstract}

Keywords: Management; BAZNAS; Impact of COVID 19.

Abstrak: Di masa pandemi ini lembaga-lembaga amil zakat dituntut untuk dapat berkontribusi dalam penanganan masalah ekonomi yang diakibatkan oleh pandemi covid-19. Yang mana zakat di khususkan untuk delapan golongan ashnaf saja, akan tetapi kondisi dari pandemi covid-19 ini berdampak terhadap banyak hal. Sehingga tujuan penelitian ini untuk mengetahui bagaimana Manajemen dan peran lembaga amil zakat terhadap penggunaan dana zakat pada korban covid-19. Penelitian menggunakan metode desk riptif analisis. Bahwa manajemen BAZNAS dimasa pademi dengan terkait 3 hal yaitu SDI, Money dan Methods. Secara keseluruhan telah baik, sehingga peran BAZNAS dalam mengatasi dampak selama pademi teratasi dan tujuan BAZNAS tercapai.

Kata Kunci: Manajemen; BAZNAS; Dampak COVID 19.

\section{PENDAHULUAN}

Kasus COVID-19 semakin menyebar dipenjuru dunia. Pada 31 Desember 2019, 27 kasus radang paru-paru tidak diketahui tiologi diidentifikasi di Kota Wuhan, provinsi Hubei di Cina (Sumarni, 2020). Sampai sekarang sudah menyebar keseluruh dunia termasuk Indonesia. Indonesia rotal kasus 1,46 juta, sembuh 1,28 juta dan meninggal 39.447 orang sedangkan bandingkan dengan seluruh dunia total 123 juta, 69,5 juta, dan meninggal dunia 2,71 juta. Bahkan perkembangan kasus
COVID-19 di Provinsi Bengkulu sampai tanggal 20 Maret 2021 jumlah positif 5239, sehat 4805 dan meninggal 149 orang (eGovernment Provinsi Bengkulu, 2021).

Banyaknya kasus yang terjadi didaerah menandakan bahwa akan banyak imbas terjadi di beberapa sektor. Salah satu sektor yang berimbas adalah sektor perekonomian. ekonomi masyarakat dunia menjadi menurun sehingga berdampak kepada kurang mampunya memenuhi keberlangsungan hidup. 
Banyak lembaga dan organisasi sosial membantu ekonomi masyarakat salah satunya adalah BAZNAS (Badan Amil Zakat Nasional) Provinsi Bengkulu.

Di masa pandemi ini lembaga-lembaga amil zakat dituntut untuk dapat berkontribusi dalam penanganan masalah ekonomi yang diakibatkan oleh pandemi covid-19. Yang mana zakat di khususkan untuk delapan golongan ashnaf saja, akan tetapi kondisi dari pandemi covid-19 ini berdampak terhadap banyak hal. Bisakah penggunaan dana zakat dialokasikan untuk penanganan korban dari dampak COVID-19(Kadir, Hakim, Syam, \& Karim, 2020).

Bisakah alokasi dana zakat penggunaan dana untuk penangan kasus COVID- 19. Sehingga tujuan penelitian ini untuk mengetahui bagaimana Manajemen dan peran lembaga amil zakat terhadap penggunaan dana zakat pada korban covid-19.

\section{METODE PENELITIAN}

Penelitian menggunakan metode deskriptif analisis yaitu penelitian yang tujuannya adalah untuk menjelaskan secara utuh mengenai setting sosial atau untuk dimaksudkan untuk kenyataan sosial dengan jalan mendeskripsikan sejumlah variabel yang berkenaan dengan masalah yang diteliti antara fenomena yang diuji.

Menurut Sugiono, penelitian kualitatif adalah penelitian dimana peneliti ditempatkan sebagai instrument kuncu, teknik pengumpulan data secara penggabungan dan analisis data bersifat induktif(Sugiyono, 2011)

Sesuai dengan permasalahan yang menjadi fokus dalam penelitian ini adalah gambaran deskriptif mengenai dinamika yang terjadi dilapangan dengan mendeskripsikan data yang peneliti peroleh sebagai hasil suatu penelitian.

\section{HASIL PENELITIAN DAN PEMBAHASAN}

\section{Profil BAZNAS Provinsi Bengkulu}

Badan Amil Zakat Nasional (BAZNAS) merupakan badan resmi dan satusatunya yang dibentuk oleh pemerintah berdasarkan keputusan Presiden RI No. 8 Tahun 2001 yang memiliki tugas dan fungsi menghimpun dan menyalurkan zakat, infa, dan sedekah (ZIS) pada tingkat Nasional. Lahirnya undang-undang Nomor 23 tahun 2001 tentang penelolaan zakat semakin mengkukuhkan BAZNAS sebagai lembaga yang berwenang melakukan pengelolaan zakat secara rasional. Dalam UU tersebut, Baznas dinyatakan sebagai lembaga pemerintah nonstruktural yang bersifat mandiri dan bertanggung jawab kepada presiden melalui Menteri Agama.

Visi dan Misi BAZNAS adalah sebagai berikut:

Visi : terwujudnya Badan Pengelola Zakat yang amanah, transparan dan profesional

Misi :

1. Meningkatkan kualitas pengelolaan ZIS hingga dapat tersalur secara merata, berhasil guna, dan berdaya guna

2. Memudahkan pelayanan bagi muzaki, munfiq, dan mutshaddiq dalam menunaikan ZIS

3. Meudahkan pelayanan bagi para mustahik dalam mendapatkan haknya

4. Meningkatkan posisi mustahik agara dapat menjadi muzaki

5. Membantu pemerintah daerah dalam meningkatkan kualitas SDM, mengentaskan kemiskinan dan memberantas praktik rentenir

Dalam melaksanakan tugasnya, berikut beberapa program BAZNAS Provinsi Bengkulu adalah sebagai berikut : 
1. Bengkulu Peduli terdiri atas bantuan biaya hidup, bantuan kemanusian, bantuan bedah rumah, bantuan anak yatim, bantuan panti asuhan dan bantuan bencana alam.

2. Bengkulu Imtaq terdiri atas bantuan rumah ibadah, bantuan TPQ/Ponpes/MDA, bantuan yayasan, bantuan Ormas Islam, Bantuan Guru Ngaji non ASN

3. Bengkulu Cerdas terdiri atas bantuan beasisiswa, bantuan pendidikan, bantuan subsidi pendidikan.

4. Bantuan Makmur terdiri atas Bantuan ekonomi produktif, bantuan pemberdayaan, bantuan ekonomi (peralatan usaha)

5. Bengkulu sehat terdiri atas Bantuan pengobatan, bantuan alat kesehatan, bantuan transportasi .

(Gunawan, Oktarina, Elwardah, \& Alfiah, 2019)

BAZNAS menjalankan empat fungsi, yaitu:(BAZNAS Provinsi bengkulu, 2019)

1. Perencanaan pengumpulan, pendistribusian dan pendayagunaan zakat

2. Pelaksanaan pengumpulan, pendistribusian dan pendayagunaan zakat;

3. Pengendalian pengumpulan, pendistribusian dan pendayagunaan zakat; dan

4. Pelaporan dan pertanggungjawaban pelaksanaan pengelolaan zakat.

Untuk terlaksananya tugas dan fungsi tersebut, maka BAZNAS memiliki kewenangan:(BAZNAS Provinsi bengkulu, 2019)

1. Menghimpun, mendistribusikan dan mendayagunakan zakat.

2. Memberikan rekomendasi dalam pembentukan BAZNAS Provinsi, BAZNAS Kabupaten/Kota, dan LAZ.

3. Meminta laporan pelaksanaan pengelolaan zakat, infak, sedekah, dan dan sosial keagamaan lainnya kepada BAZNAS Provinsi dan LAZ.
Sedangkan kebijakan mutu BAZNAS sebagai berikut : (BAZNAS Provinsi bengkulu, 2019)

1. Meningkatkan kesadaran berzakat sesuai syariah dan peraturan perundangan untuk meningkatkan kesejahteraan mustahik.

2. Memberikan layanan terbaik bagi muzaki dan mustahik.

3. Membuat program pendayagunaan zakat sesuai dengan syariah secara terencana, terukur dan berkesinambungan dalam peningkatan kesejahteraan mustahik.

4. Membina, mengembangkan dan mengkoordinasikan BAZNAS Provinsi, BAZNAS Kabupaten/Kota dan LAZ.

5. Mengembangkan sistem teknologi informasi yang handal untuk menyajikan data penerimaan, pendistribusian dan pendayagunaan zakat secara nasional.

6. Mengembangkan manajemen yang profesional, transparan dan akuntabel yang sesuai untuk lembaga keuangan syariah.

7. Membina dan mengembangkan amil yang amanah, berintegritas dan kompeten yang mampu menumbuhkan budaya kerja Islami.

8. Mengembangkan model-model terbaik pengelolaan zakat yang dapat dijadikan acuan dunia.

Adapun tujuan mutu BAZNAS

:(BAZNAS Provinsi bengkulu, 2019)

1. Mengoptimalkan penghimpunan ZIS dari kementerian, lembaga, instansi pemerintah, BUMN, BUMD, perusahaan swasta dan masyarakat sesuai peraturan perundangan.

2. Mengoptimalkan program pendistribusian dan pendayagunaan ZIS dengan melibatkan BAZNAS Provinsi, BAZNAS Kabupaten/Kota, LAZ dan berbagai institusi terkait untuk meningkatkan kesejahteraan mustahik.

3. Menguatkan kapasitas, kapabilitas dan tatakelolal BAZNAS dan LAZ.

4. Menguatkan kerjasama dengan organisasi kemasyarakatan Islam dan pihak-pihak lain 
yang relevan untuk mengoptimalkan sosialisasi dan edukasi ZIS serta dakwah.

5. Membangun sistem manajemen BAZNAS yang kuat melalui penerapan standar operasional baku dan implementasi sistem online berbasis teknologi informasi dan komunikasi pada semua aspek kerja.

6. Membangun sistem manajemen keuangan yang transparan dan akuntabel sesuai dengan syariah dan PSAK 109.

7. Menyiapkan sistem dan infrastruktur BAZNAS dan LAZ sebagai lembaga keuangan syariah di bawah pengawasan OJK.

8. Mengembangkan sistem manajemen sumber daya insani yang adil, transparan dan memberdayakan.

\section{Manajemen}

Manajemenadalah proses, suatu alur kegiatan. Di samping itu, manajemen merupakan kegiatan manajerial yang mempengaruhi perilaku anggota organisasi dan organisasi itu sendiri.Karena itu, manajemen terdiri dari 5 (lima) unsur, yaitu:pertama, man yaitu sumber daya manusia (SDM) yang ada pada sebuah lembaga. Kedua,moneyyaitu dana yang diperlukan untuk mencapai tujuan. Ketiga, methodsyaitu cara atau sistem untuk mencapai tujuan. Keempat, materialsyaitu bahan-bahan yang diperlukan dalam mencapai tujuan atau misi lembaga. Kelima, machinesyaitu alat-alat yang diperlukan(Pidarta, 2014). Namun untuk mengenai pembahasan dalam artikel ini terkait 3 hal saja, SDI, Money dan Methods.

\section{Manajemen BAZNAS}

Momentum bagi lembaga-lembaga zakat untuk ambil bagian guna membantu masyarakat yang terkena dampak dari musibah pandemi covid-19. Islam hadir sebagai rahmatan lil 'alamin yang memberikan rahmat bagi seluruh alam. Sehingga Islam dikenal sebagai ajaran universal artinya segala aktifitas manusia itu semuanya diatur dalam Islam. Islam diturunkan Allah SWT untuk mencapai tujuan-tujuan atau gagasan tertentu(Kadir et al., 2020).

Mencapai tujuan-tujuan tersebut dibutuhkanlah manajemen yang baik. pertama, man yaitu sumber daya manusia (SDM) yang ada pada sebuah lembaga.

SDM biasa kita kenal dengan Sumberdaya Insani (SDI) merupakan pelaku yang menjalankan organisasi tersebut. BAZNAS telah melakukan beberapa strategi dalam pengembangan SDI mulai dari pelatihan pengawasan, sertifikasi, tanggap darurat serta pelatihan pengoperasian layanan berbasis digital (Gunawan, Oktarina, Elwardah, \& Alfiah, 2019) sehingga tepat sekali dalam masa pademi ini yang memungkinkan tidak bisa untuk berinteraksi langsung.

Kedua, money yaitu dana yang diperlukan untuk mencapai tujuan.

Dari hasil wawancara dengan staf BAZNAS bapak Jihad menyatakan bahwa dana zakat mengalami peningkatan sangat drastis dana zakat per tahun 2020 naik sampai $105 \%$ padahal target 4,7 M dan ternyata terkumpul 5,4 M.

Dapat disimpulkan bahwa dana zakat mengalami peningkatan walaupun dalam kondisi pademi. Berarti manajemen BAZNAS dalam funding sudah baik, dan mendapati daya tarik masyarakat untuk percaya menyalurkan zakat kepada lembaga BAZNAS.

Selain itu, ujian bukan menjadi penghalang untuk menjalankan kewajiban sebagai umat Islam. Ini menandakan bahwa Islam benar rahmatan lil alamin. Saling berbagi, saling membantu dengan dana yang terkumpul banyak dapat disalurkan ke masyarakat terdampak pademi COVID 19.

Ketiga, methods yaitu cara atau sistem untuk mencapai tujuan. Ada beberapa solusi yang dilakukan BAZNAS untuk bisa membantu dampak COVID 19. Adapun 
Kebijakan BAZNAS terkait COVID 19 sebagi berikut :

1. Memberikan biaya hidup bulanan kepada mustahik yang tersebar ke semua kabupaten dan kota.

2. Memberikan modal usaha kepada mustahik.

3. Memberikan biaya pendidikan

4. Bantuan guru ngaji dan dai dai di provinsi Bengkulu.

Kebijakan ini menjadi solusi dalam penanganan dampak pademi. Tujuannya masyarakat diharapkan dapat melangsungkan kehidupan seperti biasa, dan mengembangkan atau mempertahan usaha. Jadi hal ini bisa meningkatkan UMKM pada masyarakat umum.

\section{Peran BAZNAS terhadap Penggunaan Dana Zakat Dampak COVID-19}

Kontribusi dan peran seluruh komponen bangsa menjadi sangat penting, agar dampak negatif pandemi covid-19 bisa dimitigasi dan diatasi dengan baik. Negara tidak bisa sendirian dalam hal ini. Diperlukan adanya dukungan dan kolaborasi berbagai pihak agar semua sumberdaya yang dimiliki bangsa ini dapat dimanfaatkan dengan baik. Salah satu institusi yang berperan dalam upaya penanggulangan dampak covid-19 ini adalah institusi zakat. BAZNAS dan LAZ telah menunjukkan keterlibatannya dalam kegiatan respon terhadap pandemi ini, baik ditinjau dari program kesehatan maupun program sosial ekonomi. BAZNAS Pusat sebagai contoh, hingga 25 Mei 2020, telah menggelontorkan dana sebesar Rp 28,32 miliar yang dialokasikan untuk program darurat kesehatan (39 persen), darurat sosial ekonomi (59 persen) dan pengamanan program yang ada saat ini (2 persen) (Syauqi Beik, 2020).

Ada beberapa hal langkah-langkah strategis untuk membantu pemerintah dalam mencegah penyebaran Covid-19 antara lain sebagai berikut :

\section{Peran dalam Bidang Ekonomi}

Dampak Covid-19 pada melemahnya ekonomi dunia tentu akan membuka potensi lahirnya mustahik baru. Dalam konteks global, OPZ dapat bekerjasama dengan WZF (World Zakat Forum) untuk mendiskusikan peluang pendistribusian zakat untuk pencegahan, pengobatan, dan research vaksin Covid-19. Selain itu, bekerjasama dengan WZF, OPZ global dapat mengadvokasi peran zakat dalam menghadapi lemahnya ekonomi negara-negara WZF karena Covid-19. Dalam konteks nasional dan lokal, penyaluran dan pendistribusian zakat OPZ dalam bidang ekonomi dapat dikembangkan ke arah pemberdayaan mustahik baru yang disebabkan oleh lemahnya pertumbuhan ekonomi global karena Covid-19 (Hudaefi, Junari, Zaenal, \& Ramdhoni, 2020).

Badan Amil Zakat Nasional (BAZNAS) berupaya meningkatkan kapasitas mustahik pelaku usaha mikro dan kecil dalam menghadapi dampak Pandemi Covid-19. Upaya ini dilakukan agar para pengusaha ini dapat mengubah tantangan kelesuan usaha menjadi sebuah peluang yang menguntungkan. Salah satu caranya dengan melakukan pelatihan berbagai ilmu praktis secara daring sejak Maret 2020 yang menghadirkan narasumber narasumber kompeten di bidangnya. Diantaranya mengenai digital marketing, teknik fotografi produk, tips dan trik dalam aktivitas pemberdayaan masyarakat desa, pendampingan UMKM, pemberdayaan peternak dan pemberdayaan petani.

$$
\text { Sebagai contoh BAZNAS }
$$

melaksanakan pelatihan memasak nasi kebuli yang diikuti lebih dari 10 ribu peserta secara online dan setelah pelatihan berlangsung, banyak ibu-ibu rumah tangga yang mampu membuatnya dan menjualnya ke lingkungan sekitar (BAZNAS, 2020). Sumber daya yang dimiliki masyarakat sekitar menjadi kekuatan 
pengembangan ekonomi masyarakat didaerah masing-masing.

\section{Peran dalam bidang pendidikan, sosial dan kemanusiaan}

Virus Covid-19 membuka peluang bagi OPZ untuk meluaskan perannya dalam bidang pendidikan, sosial dan kemanusiaan. Sebagai contoh, OPZ dapat mendistribusikan dana infaq untuk tindakan preventif dalam mencegah Covid-19 dari level individu. Ini dapat dilakukan dengan membagikan masker (pelindung wajah) di tempat umum. Selain itu, OPZ juga dapat melakukan kampanye bahaya Covid-19 di internal OPZ, maupun melalui media-media kampanyenya untuk masyarakat umum.

Secara spesifik dalam bidang kemanusiaan, OPZ dengan WZF bekerjasama untuk melakukan kampanye global pentingnya mengkonsumsi makanan halal, dengan mangacu kepada bukti-bukti ilmiah (Hudaefi et al., 2020).

\section{Peran dalam Bidang Kesehatan}

Sebagimana banyak diinfokan bahwa belum ada vaksin khusus untuk Covid-19. Oleh karena itu, OPZ dapat bekerjasama dengan pemangku kesehatan terkait, baik itu di tingkat global maupun nasional, untuk memperluas perannya dalam mendukung studi terkait vaksin Covid-19. Selain itu, bagi OPZ yang memiliki unit kesehatan, OPZ tersebut dapat melakukan peningkatan kapasitas atau pengadaan alat-alat laboratorium yang dapat mendeteksi pasien terjangkit Covid-19, seperti pengadaan kit CDC Covid-19 RealTime Reverse Transcriptase.

\section{Peran dalam Bidang Dakwah}

Dalam kasus SARS-CoV dan MERS$\mathrm{CoV}$, telah dikonfirmasi virus tersebut berasal dari hewan. Dalam konteks dakwah, OPZ dapat secara masif berkampanye pentingnya untuk mengkonsumsi makanan halal dan thoyyib, terutama untuk menjaga diri dari virusvirus yang ada di hewan-hewan yang tidak halal.

\section{KESIMPULAN}

Dari pembahasan diatas dapat diambil kesimpulan bahwa manajemen BAZNAS dimasa pademi dengan terkait 3 hal yaitu SDI, Money dan Methods. Secara keseluruhan telah baik, sehingga peran BAZNAS dalam mengatasi dampak selama pademi teratasi dan tujuan BAZNAS tercapai.

\section{DAFTAR KEPUSTAKAAN}

BAZNAS. 2020. Panen Raya Petani Binaan BAZNAS. BAZNA. Retrieved from https://intranet.baznas.or.id/attachment /newsletter/MTE4NzE2MDM3MTc0N zI.pdf

BAZNAS Provinsi bengkulu. 2019. Tentang BAZNAS Provinsi Bengkulu. Retrieved March 22, 2021, from BAZNAS Provinsi bengkulu website: http://bengkulu.baznas.go.id/halaman/d etail/tentang-baznas

eGovernment Provinsi Bengkulu, T. 2021. COVID 19 Provinsi Bengkulu. Retrieved March 21, 2021, from https:// covid19.bengkuluprov.go.id/

Gunawan, Y., Oktarina, A., Elwardah, K., \& Alfiah, E. 2019. Human Resource Management Strategy in Improving Baznas Performance in Digital Era. JEBI (Jurnal Ekonomi Dan Bisnis Islam), 4(2), 137.

https://doi.org/10.15548/jebi.v4i2.240

Hudaefi, F. A., Junari, U. L., Zaenal, M. H., \& Ramdhoni, R. 2020. Mencegah COVID19: Apa Peran Organisasi Pengelola Zakat? Badan Amil Zakat Nasional, (February), 1-10. https://doi.org/10.13140/RG.2.2.23370. 11207

Kadir, A., Hakim, M. R., Syam, F., \& Karim, M. S. 2020. Pengunaan Dana Zakat Pada Korban Covid-19 Perspektif Maqashid Syariah. Al-Tafaqqub: Journal of Islamic Law, 
1(2), 107. https://doi.org/10.33096/altafaqquh.v1i2.61

Pidarta, M. 2014. Manajemen Pendidikan Indonesia. Jakarta: PT Rineka Cipta.

Sugiyono. 2011. Metode Penelitian Kuantitatif,Kualitatif dan R\&D. Bandung: Alfabeta.

Sumarni, Y. 2020. Manajemen Ekonomi Islam dalam Menangani Pandemi Coronavirus Disease (COVID-19) di Indonesia Yenti.
Jurnal BAABU AL-ILMI: Ekonomi Dan Perbankan Syariah, 21(1), 1-9. Retrieved from http://mpoc.org.my/malaysianpalm-oil-industry/

Syauqi Beik, I. 2020. Zakat dan Penanganan Covid-19. Retrieved March 21, 2021, from BAZNAS website: http://baznas.go.id/pendistribusian/kolo $\mathrm{m} /$ direktur-pp/2511-zakat-danpenanganan-covid-19 